\title{
To what extend the dam dredging can influence the background level of metals in the Rhine River: using chemical and biological long-term monitoring to answer
}

\author{
Jérémie D. Lebrun ${ }^{1,2, *}$, Marine Dufour ${ }^{1}$, Emmanuelle Uher ${ }^{1,2}$, Juliette Faburé ${ }^{3}$, Raphaël Mons ${ }^{5}$, \\ Rayna Charlatchka ${ }^{6}$, Catherine Gourlay-Francé ${ }^{7}$, Lise C. Fechner ${ }^{4}$ and Benoît J.D. Ferrari ${ }^{8}$ \\ ${ }^{1}$ Irstea, UR HBAN-ARTEMHYS, CS 10030, 92761 Antony Cedex, France \\ ${ }^{2}$ Federation of Research FIRE, FR-3020, 75005 Paris, France \\ ${ }^{3}$ UMR ECOSYS, INRA, AgroParisTech, Université Paris-Saclay, 78026 Versailles, France \\ ${ }^{4}$ Ifremer, 92138 Issy-les-Moulineaux, France \\ 5 Irstea, UR MALY, CS 70077, 69626 Villeurbanne, France \\ ${ }^{6}$ EDF R\&D LNHE 6, 78401 Chatou, France \\ 7 ANSES, DEPR, 94701 Maisons-Alfort Cedex, France \\ ${ }^{8}$ Centre Ecotox Eawag/EPFL, EPFL-ENAC-IIE-GE, Station 2, 1015 Lausanne, Switzerland
}

\begin{abstract}
Dredging generates remobilisation of sediments contaminated by non-degradable compounds such as metals, to which aquatic organisms can be exposed. This study aims at assessing the environmental impact of sediments remobilised in the Rhine River (France) during the dredging of Marckolsheim dam by pumping/dilution in 2013 on metal speciation and organisms' exposure. The monitoring coupling chemical and biological tools was performed 2 years before dredging operation on 2 sampling sites, upstream and downstream from the discharge of pumping/dilution, to acquire data on the natural variability of labile (DGT as passive samplers), dissolved and particulate concentrations of $\mathrm{Cd}, \mathrm{Co}, \mathrm{Cr}, \mathrm{Cu}, \mathrm{Ni}, \mathrm{Mn}, \mathrm{Pb}$ and $\mathrm{Zn}$ in $\mathrm{Rhine}$ during full hydrological cycles. In parallel, size-calibrated zebra mussels were transplanted at both sites to monitor continuously metal bioavailability from particulate and dissolved fractions. This long-term monitoring allowed the establishment of reference baselines of Rhine water and mussels' contamination levels and subsequently, the detection of averred environmental changes due to the dredging. Indeed, Co and Mn accumulations in mussels exposed to the discharge were consistent with increasing labile species in Rhine whereas ones of $\mathrm{Cr}$ and $\mathrm{Pb}$ were likely due to an enhanced particulate bioavailability. Whatever the exposure route, the mussels recovered their basal metal contents 2 weeks after the end of dredging, suggesting a transient impact of sediment remobilisation on bioaccumulation. This long-term monitoring highlights the interest of coupling chemical and biological time-integrated tools for a better assessment of environmental risks because metallic exchanges between organisms and their media are complex and metal-specific.
\end{abstract}

Keywords: active biomonitoring / Dreissena polymorpha / DGT / metal bioavailability / natural variability

Résumé - Évaluation de la remobilisation de sédiments contaminés par des métaux dans le Rhin au cours du dragage d'un barrage grâce à un suivi chimique et biologique à long terme. Une opération de dragage engendre la remobilisation de sédiments contaminés par des composés non dégradables tels que les métaux, auxquels les organismes aquatiques peuvent être exposés. Cette étude vise à évaluer l'impact environnemental de la remobilisation de sédiments chargés en métaux dans le Rhin lors du dragage du barrage de Marckolsheim par pompage/dilution en 2013 sur la spéciation et l'exposition des organismes aux métaux. La surveillance chimique et biologique a été effectuée 2 ans avant l'opération de dragage sur 2 sites d'échantillonnage, en amont et en aval de la zone de rejet, pour acquérir des données sur l'évolution naturelle des concentrations labiles, dissoute et particulaires en $\mathrm{Cd}, \mathrm{Co}, \mathrm{Cr}, \mathrm{Cu}, \mathrm{Ni}, \mathrm{Mn}, \mathrm{Pb}$ et en $\mathrm{Zn}$ dans le Rhin pendant des cycles hydrologiques complets. En parallèle, des moules zébrées calibrées ont été transplantées sur les deux sites pour surveiller la biodisponibilité particulaire et dissoute des métaux. Cette

\footnotetext{
*Corresponding author: jeremie.lebrun@irstea.fr
} 
surveillance à long terme a permis d'établir des niveaux de contamination de référence du Rhin et des moules, et ainsi de détecter des changements environnementaux dus au dragage. En effet, les accumulations de Co et de Mn dans les moules exposées au rejet concordaient avec l'augmentation de leurs formes labiles dans l'eau du Rhin alors que celles de $\mathrm{Cr}$ et $\mathrm{Pb}$ étaient probablement liées à une biodisponibilité particulaire favorisée par la remobilisation de sédiments. Quelle que soit la voie d'exposition, les moules ont récupéré leur teneur basale en métaux 2 semaines après la fin du dragage, suggérant un impact transitoire de la remobilisation des sédiments sur la bioaccumulation. Cette surveillance à long terme met aussi en évidence l'intérêt de coupler des outils chimiques et biologiques pour une meilleure évaluation des risques environnementaux car les échanges métalliques entre les organismes et leurs milieux sont complexes et dépendent du métal considéré.

Mots-clés : biosurveillance active / Dreissena polymorpha / DGT / Biodisponibilité / Variabilité naturelle

\section{Introduction}

The hydroelectric dam of Marckolsheim (Northeast of France) is one of numerous structures located along the $1200 \mathrm{~km}$ of the Rhine River, where sediments have been accumulating for several decades. For the maintenance and the safety of the dam, a dredging operation which consisted of pumping/dilution of accumulated sediments with direct discharge in the channel of Alsace was organized in 2013 by the French firm EDF as manager of the dam in accordance with local regulations for the protection of aquatic ecosystem. Nevertheless, a dredging operation involves remobilisation of sediments that are potentially contaminated by non-degradable compounds such as metals, and subsequently may lead to alterations of the aquatic ecosystem. Even at low concentrations, metallic contamination can negatively affect aquatic organisms, alter community structures and ecosystem functioning (Roussel et al., 2008; Bourgeault et al., 2010b; Fechner et al., 2012; Faburé et al., 2015).

The impact of contaminants on aquatic ecosystems is usually assessed by spot sampling of environmental matrices. The determination of metal concentrations in the water column can then be compared to Environmental Quality Standards or EQSs defined by European regulations for the protection of aquatic life (Directive 2013/39/UE, 2013). Locally, the International Commission for the Protection of the Rhine (CIPR) have defined reference objectives not to exceed for the metallic contamination of suspended particulate matter or SPM (Report CIPR n 193, 2008). Nevertheless, these chemical analyses do not give information about the bioavailability of metals that is the fraction internalized in biological tissues and potentially toxic for biota (Bourgeault et al., 2010b; Lebrun et al., 2012). Besides, they provide only a snapshot of the occurrence of metals that is not representative of temporal fluctuations of contamination levels and metal partitioning related to environmental and hydrological conditions or/and changes in pollution discharges. Consequently, these routine analyses can be insufficient to assess the impact of metals on environmental health (Faburé et al., 2015).

During the last decades, chemical and biological tools have been developed in order to obtain integrative measurements of metallic contamination and its potential risk for aquatic ecosystems. Among the chemical tools that have been developed, the Diffusive Gradient in Thin-films technique (DGT) is a speciation method that allows for the estimation of time-weighted average concentration of labile metals through in situ passive sampling (Tusseau-Vuillemin et al., 2007;
Uher et al., 2011). The DGT-labile metallic fraction, which is composed of free inorganic metals and weak organic complexes, has been shown to be close to the bioavailable fraction for freshwater organisms exposed only by aqueous route (Ferreira et al., 2009; Pellet et al., 2009). In terms of biological tools, bioaccumulation studies using encaged organisms have gained importance for environmental risk assessment (Bervoets et al., 2005; Besse et al., 2012). Indeed, metal determination in organisms provides an integrative measurement of local metal bioavailability at the transplantation site insofar as the different exposure routes of transplanted organisms and their ability to regulate internalized metals and geochemical effects on metal uptake are taken into account in the bioaccumulation process (Rainbow, 2007; Verschoor et al., 2012; Lebrun et al., 2014).

As filter-feeders, bivalves accumulate metals from both the dissolved phase (aqueous exposure) and suspended matter (dietary exposure) of the water column, and thus constitute interesting candidates to monitor particulate contamination. Because of its high filtration ability and ease to collect, the zebra mussel Dreissena polymorpha has been often used in European monitoring programs over the last decades to assess metal bioavailability in situ (Bervoets et al., 2005; Bourgeault et al., 2011). Nevertheless, metal bioaccumulation is influenced by various environmental factors such as temperature, physicochemical properties of water and suspended matter, and temporal fluctuations of all environmental parameters (Verschoor et al., 2012; Lebrun et al., 2015). Consequently, reliable interpretation of bioaccumulation data requires the establishment of baselines integrating the natural variability of bioaccumulation on large temporal scales. Such establishment through the definition of a normal range of bioaccumulation levels in reference conditions offers the promising lines of enquiry to detect and to quantify environmental changes due to anthropogenic pressures such as dredging (Barrett et al., 2015).

This study aims at assessing the environmental impact of metal-contaminated sediments remobilised in the Rhine River during the dredging of the Marckolsheim dam. Thus, a long-term monitoring using both chemical and biological tools was performed on two sampling sites located upstream and downstream from the discharge area of pumping/dilution. Environmental monitoring began 2 years before the operation in order to acquire data on the natural evolution of metal contamination of the Rhine water during full annual hydrological cycles (temporal variations related to seasons, floods, etc. were thus taken 


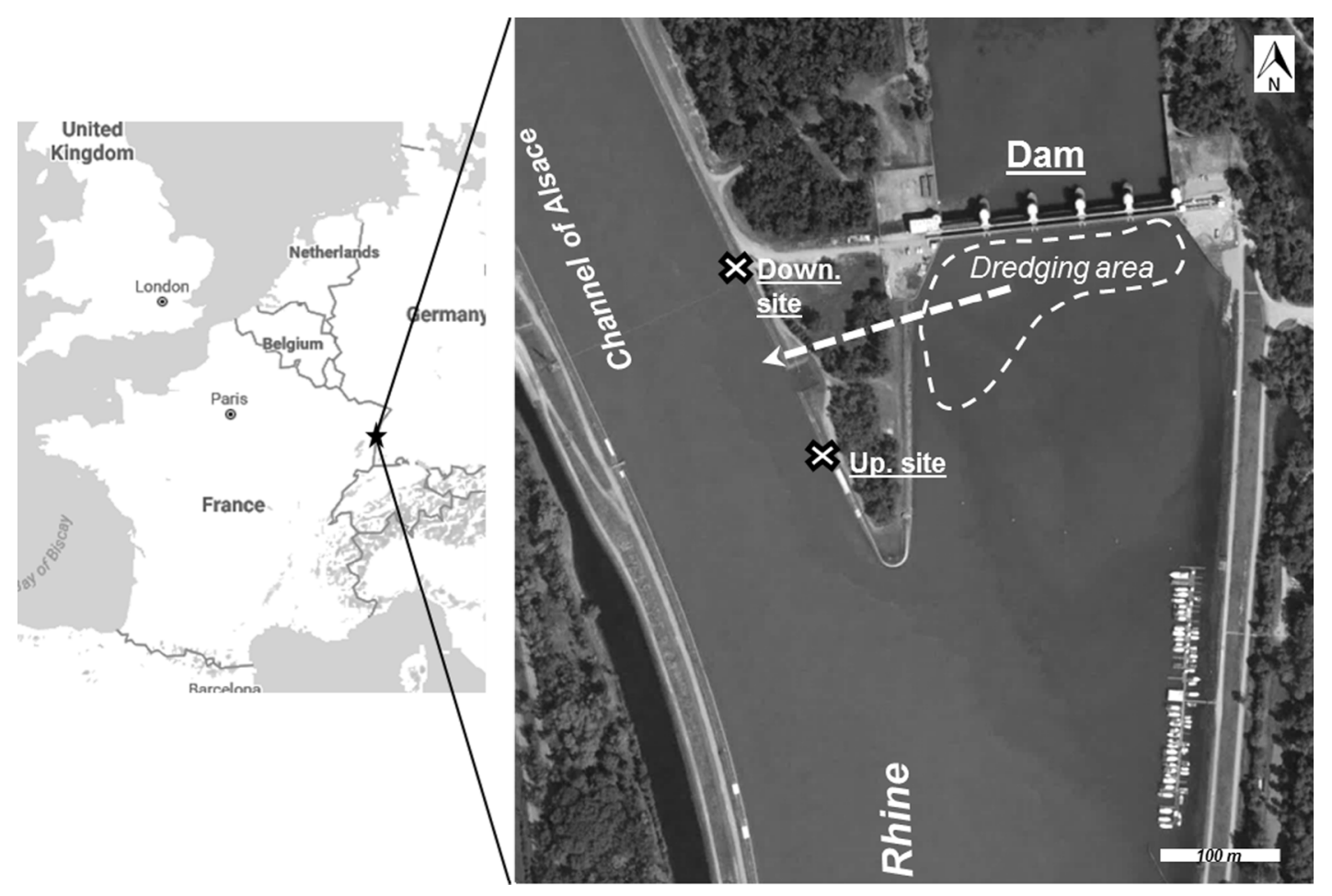

Fig. 1. Map showing the experimental sites upstream and downstream from the discharge area of pumping/dilution in the channel of Alsace during dredging of the Marckolsheim dam.

into account). From March 2011 to July 2013, DGT-labile, dissolved and total concentrations of $\mathrm{Cd}, \mathrm{Co}, \mathrm{Cr}, \mathrm{Cu}, \mathrm{Ni}$, $\mathrm{Mn}, \mathrm{Pb}$ and $\mathrm{Zn}$ were monthly measured at both sites as well as metal concentrations in SPM. In parallel, size-calibrated zebra mussels were encaged and transplanted at both sites to monitor metal bioavailability.

\section{Materials and methods}

\subsection{Experimental sites and long-term monitoring}

The hydroelectric dam of Marckolsheim (N $48^{\circ} 6^{\prime} 23.18^{\prime \prime}$; $\left.\mathrm{E} 7^{\circ} 34^{\prime} 47.165^{\prime \prime}\right)$ is located on the branch of the Rhine river, just after its junction with the channel of Alsace. The dredging operation started in February 2013 and lasted 5 weeks (from 12th February to 19th March, 2013) in the compliance with quality guidance values (metal concentrations in sediments to be dredged were given in Suppl. Mat. see Tab. S1). This operation was achieved by pumping/diluting the sediment (dilution rate of $1: 10 \mathrm{v}: \mathrm{v}$ ) with direct discharge of the effluent $\left(180 \mathrm{~m}^{3} \mathrm{~h}^{-1}\right) 100 \mathrm{~m}$ away in the channel of Alsace. To acquire data on full annual hydrological cycles, the monitoring began 2 years before the dredging from March 2011 to July 2013 and was performed at the two sampling sites located $100 \mathrm{~m}$ either upstream or downstream from the discharge area of pumping/ dilution in the channel (Fig. 1). The distance between both sites is thus of $200 \mathrm{~m}$.

From March 2011, water samples were collected monthly at each experimental site until the dredging, then bi-monthly after the dredging, for the determination of dissolved organic carbon (DOC), total suspended solids (TSS), global physicochemical parameters (major ions, $\mathrm{pH}$ and temperature; Tab. 1) and metallic concentrations. Temperature and $\mathrm{pH}$ were directly measured at each sampling site. For the total metal fraction, $50 \mathrm{~mL}$ of raw water was sampled in a polypropylene tube (SCP Science). For the dissolved metal fraction, $30 \mathrm{~mL}$ of raw water was filtered on site through a $0.45 \mu \mathrm{m}$ PES syringe filter (Millipore) and transferred to a $50 \mathrm{~mL}$ polypropylene tube (Lebrun et al., 2015). Samples were brought back to the laboratory in a cool box.

From March 2012, three DGTs were simultaneously deployed at each site, retrieved and replaced by new ones either monthly (before dredging) or bi-monthly (after dredging); to monitor continuously the DGT-labile contamination. DGTs were comprised of $0.8 \mathrm{~mm}$-thick restrictive diffusive gels and a $0.4 \mu \mathrm{m}$ PC filter (DGT research, Landcaster, UK) (Uher et al., 2011). In order to obtain time-integrated measurements of the contamination of suspended particulate matter (or SPM) in the Rhine water, a trap was deployed upstream from the discharge area of pumping/dilution (Priadi et al., 2011). Trapped particulate matter was monthly collected from January to October 2012 and also from March to July 2013 for determination of metal concentration in SPM.

Immersion systems were specially designed for the deployment of time-integrative tools at each experimental site (see illustration in Suppl. Mat.). They consisted of two sheathed cables weighted at their ends with cement coated in a PVC cylinder in order to ease the immersion of systems along the ramp of the channel of Alsace. A perforated support and a dobby were fixed on the cables to insert DGTs and the cages containing mussels respectively. The systems were designed to protect transplanted animals from exterior factors such as friction or predation. 
Table 1. Water physicochemical parameters measured during long-term monitoring on the Rhine River. Bold values are means of water samplings performed at both upstream and downstream sites $(n=41)$ from March 2011 to July 2013. Minimal and maximal values are in italics. RSD is relative standard deviation, TSS is total suspended matter and DOC is dissolved organic carbon.

\begin{tabular}{lrrr}
\hline & Mean & min-max & RSD (\%) \\
\hline Temperature $\left({ }^{\circ} \mathrm{C}\right)$ & $\mathbf{1 2 . 7}$ & $1.5-24.8$ & 48.7 \\
Discharge $\left(\mathrm{m}^{3} \mathrm{~s}^{-1}\right)$ & $\mathbf{9 8 8 . 3}$ & $563-1652$ & 29.9 \\
$\mathrm{pH}$ & $\mathbf{7 . 9}$ & $6.6-10.9$ & 13.3 \\
$\mathrm{TSS}\left(\mathrm{mg} \mathrm{L}^{-1}\right)$ & $\mathbf{9 . 9}$ & $2.2-37.2$ & 77.4 \\
$\mathrm{DOC}$ & $\mathbf{2 . 0}$ & $1.3-3.2$ & 18.5 \\
$\mathrm{Na}^{+}$ & $\mathbf{1 2 . 5}$ & $7.9-18.7$ & 24.5 \\
$\mathrm{~K}^{+}$ & $\mathbf{1 . 8}$ & $1.2-2.5$ & 23.3 \\
$\mathrm{Mg}^{2+}$ & $\mathbf{8 . 4}$ & $5.1-10.7$ & 17.5 \\
$\mathrm{Ca}^{2+}$ & $\mathbf{6 4 . 6}$ & $45.2-79.6$ & 11.9 \\
$\mathrm{Cl}^{-}$ & $\mathbf{1 3 . 9}$ & $8.6-20.2$ & 28.3 \\
$\mathrm{NO}_{3}{ }^{2-}$ & $\mathbf{6 . 8}$ & $4.5-9.2$ & 23.6 \\
$\mathrm{SO}_{4}{ }^{2-}$ & $\mathbf{2 4 . 7}$ & $21.7-26.3$ & 5.8 \\
$\mathrm{HCO}^{-}$ & $\mathbf{1 6 7 . 6}$ & $154.7-205.3$ & 12.4 \\
\hline
\end{tabular}

\subsection{Mussels' collection and transplantation}

Zebra mussels were collected in the channel of the East (Meuse, Northeast of France), manually removed from rocks using a scalpel and size-calibrated according to their length (19-24 mm), as previously described (Bourgeault et al., 2010b). In order to obtain enough organisms for a continuous monitoring of metal bioavailability, 3 collections about 750 mussels were required (i.e. in March, December 2011 and December 2012). In the laboratory, mussels were caged at a number between 25 and 30 individuals per cage and maintained in water from the channel site until their deployment on both experimental sites the following day (Tab. S2 in Suppl. Mat.). For each collection, one cage of mussels was not deployed and was used for determination of the reference condition index after their handling and caging.

During the long-term monitoring, one cage of mussels was monthly retrieved from each site, and then bimonthly after the dredging operation for closer monitoring of metal bioaccumulation after the exposure of mussels to remobilised sediments. Mussels were brought back to the laboratory with local water in cooled containers. In the laboratory, mussels were counted and immediately dissected for the determination of the condition index, CI. Over the three deployment periods, the average survival rates of mussels caged at upstream and downstream sites were respectively $91.4 \pm 16.5$ and $91.3 \pm 11.3 \%$ (see Tab. S2 and Fig. S4 in Suppl. Mat.). As recommended by a previous study (Galvao et al., 2015), the CI was calculated as the ratio between the wet weight of soft tissues and the total length of shells and used to monitor the physiological status during transplantation (Bourgeault et al., 2010b; Bourgeault et al., 2011). For the first two transplantations of March and December 2011, significant decreases in weight associated with increases in mortality, were observed during summers 2011 and 2012 when compared to the reference CI established on freshly-collected organisms (Fig. S4). Such decreases in CI have been related to low food availability and/or reproductive stage (e.g. primary spawning during the summer) in freshwater and marine mussels
(Bourgeault et al., 2010b; Bourgeault et al., 2011; Galvao et al., 2015). Consequently, bioaccumulation data from caged mussels retrieved after July 2011 and 2012 were not included in the results insofar as CI decreases can reflect the biological alterations of mussels including metal bioaccumulation. For the third transplantation, no significant variation in CI was observed from December 2012 to July 2013. Thus, the physiological status of caged mussels remained stable during the dredging operation.

\subsection{Analytical procedures}

For metal determination in SPM, $0.5 \mathrm{~g}$ of trapped matter was mineralized by treatment with HNO3 (69.5\%, for trace analysis, Fluka) and $\mathrm{HCl}(>37 \%$, for trace analysis, Fluka) on a hotblock (Digiprep, SCP Science) following an adaptation of the US EPA 3050B. For the determination of total metal concentrations in water, raw sample was acidified with $\mathrm{HNO}_{3}$ at $1 \% \mathrm{v} / \mathrm{v}$ and mineralized by treatment with $\mathrm{HNO}_{3}$ and $\mathrm{HCl}$ on a hotblock following an adaptation of the US EPA 3010A method (Uher et al., 2011). For dissolved metal concentrations, water filtrates were acidified with $\mathrm{HNO}_{3}$ at $1 \% \mathrm{v} / \mathrm{v}$. Total and dissolved water samples were stored at $4{ }^{\circ} \mathrm{C}$ until they were analysed by inductively coupled plasma mass spectrometry (ICP-MS; X series 2, Thermo Fisher Scientific) to determine $\mathrm{Cd}, \mathrm{Co}, \mathrm{Cr}, \mathrm{Cu}, \mathrm{Mn}, \mathrm{Ni}, \mathrm{Pb}$ and $\mathrm{Zn}$ concentrations in water. Overall the values were above the limits of quantification (LoQ) except for 33, 11 and 12 samples (out of 45) for dissolved $\mathrm{Cd}, \mathrm{Cr}$ and $\mathrm{Pb}$ respectively, and 8 samples for total $\mathrm{Cd}$. Values below the LoQ were replaced by the LoQ/2 for calculation of the means. Recoveries of standards (NIST 1640a) were within $98-104 \%$ and relative standard deviations were $<6 \%$ between the different analysis dates. The particulate metal concentrations were determined by substituting the dissolved fraction from the total fraction.

After elution of the DGT resins in $1 \mathrm{ml}$ of $\mathrm{HNO}_{3} 1.2 \mathrm{M}$, eluates were directly analysed by ICP-MS. The DGT-labile metal concentrations were calculated using the method 
adapted by Uher et al. (2011) taking into account the deployment time. The soft bodies of mussels coming from the same cage were pooled (i.e. 22 to 30 for the upstream site or 18 to 30 individuals for the downstream site according to the survival rate (Tab. S2)), lyophilized during $24 \mathrm{~h}$, weighted and digested by adding nitric acid and hydrogen peroxide according to the digestion procedure previously described (Bourgeault et al., 2010b). Digested samples were then analysed by ICP-MS to determine concentrations of $\mathrm{Cd}, \mathrm{Co}$, $\mathrm{Cr}, \mathrm{Cu}, \mathrm{Mn}, \mathrm{Ni}, \mathrm{Pb}$ and $\mathrm{Zn}$ in mussels and expressed in $\mu \mathrm{g}$ of metal per $\mathrm{g}$ of dry weight $\left(\mu \mathrm{g} \mathrm{g}_{\mathrm{dw}}^{-1}\right)$. The digestion method was successfully validated by a reference material (Mussel Tissue ERM-CE278, with recoveries within $83-128 \%$, as min-max values for all cofounded analyses dates and metals).

\subsection{Statistical analysis}

Normal ranges of contamination levels were established for each water metallic fractions (i.e. labile, dissolved and total) and for caged mussels in order to quantify their natural variability in reference conditions and thus, to detect changes related to the dredging operation. These normal ranges and their prediction intervals were defined from all data collected during the long-term monitoring (excluding samplings performed during the dredging operation), according to the statistical procedure described in Barrett et al. (2015). This statistical method has the advantage to take into account the sampling size for more reliable determination of $95 \%$ confidence intervals (as opposed to the usual "mean $\pm 1.96 \times$ SD"), notably when $n<50$. All data subsets were first tested for normality using the Shapiro-Wilkinson test $(33 \leq n \leq 45$; except for dissolved $\mathrm{Cd}$ with $n=10$ because of numerous values $<$ LoQ). P-values were always $<5 \%$ (except for Co and $\mathrm{Ni}$ in mussels with p-values $<10 \%$, and for labile $\mathrm{Co}$ and $\mathrm{Ni}$, dissolved $\mathrm{Ni}$ and $\mathrm{Pb}$, total $\mathrm{Cu}$ and $\mathrm{Zn}$ with $\mathrm{p}$-values $<15 \%$ ).

To assess the respective influences of different environmental factors and water metallic fractions on metal bioaccumulation in caged mussels, analyses of covariance (ANCOVA) were performed. We considered the different collection periods (for mussels) and the transplantation sites as categorical variables; major physicochemical parameters (i.e. temperature, TSS, calcium, sodium), particulate and dissolved fractions in water were considered as co-variable $(>350$ data per metal). Since the filtration rate of mussels depends on TSS concentration (Bourgeault et al., 2011), particulate metal concentrations were expressed in $\mu \mathrm{g}$ of metal per $g$ of TSS. During the dredging operation, differences in contamination levels between the upstream and downstream sites were explored with the Mann-Whitney's non-parametric test $(U$ test; $P<0.05)$. All statistical tests were performed with XLStat (Addinsoft).

\section{Results and Discussion}

\subsection{Evaluation of the ambient metal concentration in the Rhine River}

Dissolved and total concentrations were monitored both upstream and downstream from the discharge area of pumping/ dilution, from March 2011 to July 2013. During this long-term

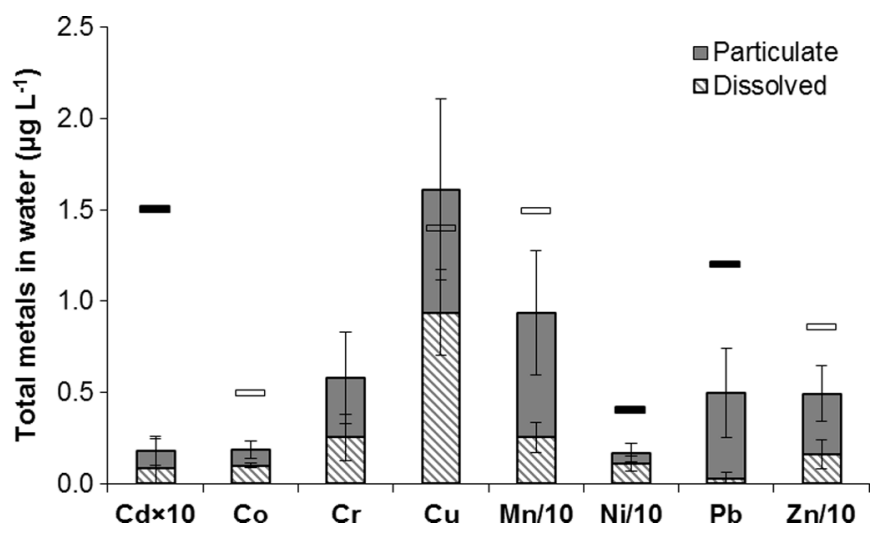

Fig. 2. Total metal concentrations in the Rhine water and metal partitioning between dissolved and particulate fractions. Bars are means obtained for both cofounded sites during the long-term monitoring ( $n=45$ water samples for both confounded sites \pm SD) from March 2011 to July 2013. Thick lines are quality standards defined by European (full line) or French (emptied line) regulations. For $\mathrm{Cd}, \mathrm{Mn}, \mathrm{Ni}$ and $\mathrm{Zn}$, concentrations were adapted by using a scaling factor.

monitoring, major temporal fluctuations were observed for total $\mathrm{Cd}$ and dissolved $\mathrm{Cd}$ and $\mathrm{Pb}$ (with $\mathrm{RSD}<50 \%$ ) (see Suppl. data, Figs. S1 and S2). The acquisition of environmental datasets allowed for the quantification of the natural variability of contamination levels of the Rhine water of the channel of Alsace during full hydrological cycles and thus, to propose reference baselines of dissolved and total metal contaminations.

The total metal concentrations and metal partitioning between dissolved and particulate fractions averaged on the whole monitoring period are shown in Figure 2. By way of comparison, the total concentrations for all tested metals are comparable to measurements performed in the Seine River at a site upstream from the Paris megacity (Lebrun et al., 2015). Besides, similar metal partitioning between dissolved and particulate fractions was observed along the Seine axis (Priadi et al., 2011; Lebrun et al., 2015). Thus, most metals were found in low quantities, confirming a diffuse multi-metallic pressure on experimental sites. Nevertheless, most of them and especially for $\mathrm{Mn}$ and $\mathrm{Pb}$ were found in the particulate fraction, which can constitute an important source of contamination for mussels.

By way of comparison, mean concentrations of the longterm monitoring did not exceed the existing EQSs based on dissolved concentrations for $\mathrm{Cd}, \mathrm{Ni}$ and $\mathrm{Pb}$ (i.e. $0.15,4.0$ and $1.2 \mu \mathrm{g} \mathrm{L}^{-1}$ ) and the provisional EQSs for $\mathrm{Cu}$ and $\mathrm{Zn}$ (i.e. 1.4 and $8.6 \mu \mathrm{g} \mathrm{L}^{-1}$ ) (Directive 2013/39/UE, 2013; Lebrun et al., 2014). In the same way, mean dissolved concentrations were lower than EQSs proposed for $\mathrm{Co}$ and $\mathrm{Mn}$ (i.e. 0.5 and $15.0 \mu \mathrm{g} \mathrm{L}^{-1}$ ) by French regulatory agencies (Bisson et al., 2006; Bisson et al., 2011). This suggests a local level of metals in the Rhine acceptable for aquatic life and indigenous populations, according to current European and French regulations for the considered metals. Besides, this strengthens the interest of assessing the environmental impact of the dredging operation on water quality of the Rhine. Nevertheless, the existing EQSs are insufficient to monitor a potential 
particulate contamination that could be generated by the remobilisation of contaminated sediments during dredging. Thus, using filter-feeders is particularly suitable to assess the bioavailability of both dissolved and particulate metals (Bervoets et al., 2005; Bourgeault et al., 2011).

\subsection{Quantifying natural variability of metal bioaccumulation in caged mussels}

Bioaccumulated metals in mussels are presented in Figure 3. As previously observed for dissolved and total metal concentrations in water, basal contamination levels of mussels were similar to those observed in zebra mussels transplanted over a 11-month monitoring experiment in a the sampling site mentioned above located upstream from Paris in the Seine river (Bourgeault et al., 2011). During annual hydrological cycles, the highest variations in metal contents in caged mussels were observed for $\mathrm{Cr}, \mathrm{Ni}$ and $\mathrm{Pb}$ (RSD 40-50\%; dredging period excluded). The lowest variations were for $\mathrm{Cu}$ and $\mathrm{Zn}(\mathrm{RSD}<15 \%)$, which are essential metals known to be actively regulated by aquatic organisms including bivalves and are required at levels relatively constant to meet the organisms' physiological needs (Bourgeault et al., 2010a; Lebrun et al., 2012; Verschoor et al., 2012; Lebrun et al., 2014).

The natural variability of metal bioaccumulation in caged mussels were quantified through $95 \%$ prediction intervals, in order to detect environmental changes during the long-term monitoring (Barrett et al., 2015). Thus, an impact of dredging was detected for 4 (out of 8) tested metals, i.e. $\mathrm{Cr}\left(3.7 \mu \mathrm{g} \mathrm{g}_{\mathrm{dw}}^{-1}\right)$, $\mathrm{Mn}\left(40.5 \mu \mathrm{g} \mathrm{g}_{\mathrm{dw}}^{-1}\right), \mathrm{Pb}\left(1.1 \mu \mathrm{g} \mathrm{g}_{\mathrm{dw}}^{-1}\right)$ and to a lesser extent Co $\left(1.0 \mu \mathrm{g} \mathrm{g}_{\mathrm{dw}}^{-1}\right)$. For these metals, metal concentrations in mussels caged at the downstream site diverged significantly from the normal distribution (Fig. 3), demonstrating a noteworthy exposure of the mussels to bioavailable metals from the discharge of the dredging operation. Regarding $\mathrm{Ni}$ and $\mathrm{Zn}$, significant changes in metal contents in mussels caged at both experimental sites, notably at the downstream site, were observed out of dredging just before the beginning of the maintenance operation. These changes in metal content in mussels were not related to any significant change in exposure levels, i.e. total, dissolved or labile concentrations in water (Figs. S1-S3). However, they were likely due to a single event that had resulted in the $\mathrm{Ni}$ and $\mathrm{Zn}$ concentrations in the particulate fractions being significantly higher than the mean concentrations. Indeed, particulate $\mathrm{Ni}$ and $\mathrm{Zn}$ concentrations were $128.3 \mathrm{mg}_{\mathrm{Ni}} \mathrm{kg}_{\mathrm{TSS}}^{-1}$ and $1011.9 \mathrm{mg}_{\mathrm{Zn}} \mathrm{kg}_{\mathrm{TSS}}^{-1}$ for the sampling point just before the beginning of dredging whereas the means averaged on the monitoring period were $52.2 \pm 34.4 \mathrm{mg}_{\mathrm{Ni}} \mathrm{kg}_{\mathrm{TSS}}^{-1}$ and $407.7 \pm 246.5 \mathrm{mg}_{\mathrm{Zn}} \mathrm{kg}_{\mathrm{TSS}}^{-1}$. Our results thus support the relevance of carefully quantifying the natural variability of bioaccumulation levels in order to detect environmental changes, whatever their origin: dredging in the case of $\mathrm{Co}, \mathrm{Cr}, \mathrm{Mn}$ and $\mathrm{Pb}$ or punctual overloading of metals in the particulate fraction in the case of $\mathrm{Ni}$ and $\mathrm{Zn}$.

\subsection{Factors influencing metal bioaccumulation in caged mussels during long-term monitoring}

To explain the variability of metal bioaccumulations previously observed in reference conditions (i.e. out of dredging period), the relative contributions of environmental factors to variations in metal contents in caged mussels were investigated by analyses of covariances (ANCOVA), as presented in Table 2. Statistical analyses indicated no significant spatial effect of the transplantation sites on bioaccumulation for all metals tested, providing an opportunity for further inter-site comparisons. On the contrary, the mussel collection period (year) appears to be a factor influencing $\mathrm{Cd}$, $\mathrm{Cr}, \mathrm{Cu}, \mathrm{Ni}$ and $\mathrm{Zn}$ contents, in spite of careful size-calibration of collected organisms and the choice of a unique collection site. This could be explained by differences in the physiological stage of collected mussels from one year to another because of changes in their life history and in environmental conditions inherent to the collection period. Indeed, mussels were collected twice in winter (December 2011 and 2012) and once in spring (March 2011). Variations in metal bioaccumulation have been reported in zebra mussels according to their reproductive stage during biomonitoring studies (Kraak et al., 1991; Kwan et al., 2003). Thus, the life history of caged mussels contributes to the natural variability in metal bioaccumulation quantified in this long term monitoring.

Concerning the physicochemical factors, significant effects of water temperature on bioaccumulation was observed only for $\mathrm{Mn}$ and of TSS for $\mathrm{Ni}, \mathrm{Pb}$ and $\mathrm{Zn}$. For water temperature, this parameter has been reported to exert a negligible influence on bioaccumulation of various metals in marine mussels Mytilus edulis (Baines and Fisher, 2008). For TSS, it is well known that this parameter is directly related to the filtration rate of bivalves and subsequently, to metal bioaccumulation (Bourgeault et al., 2011). This is consistent with the previous observations, where punctual overloading of $\mathrm{Ni}$ and $\mathrm{Zn}$ in TSS was associated with an increase in their accumulation in caged mussels. Furthermore, DOC stimulated the bioaccumulation of $\mathrm{Cd}$ and $\mathrm{Mn}$. DOC has been shown to contribute up to $50 \%$ of the carbon need of zebra mussels, which can increase $\mathrm{Cd}$ uptake insofar as both carbon and $\mathrm{Cd}$ assimilation efficiencies were correlated in this species (Roditi et al., 2000).

With respect to other chemical factors, $\mathrm{pH}$ increased the bioaccumulation of $\mathrm{Cd}$ whereas decrease one of $\mathrm{Cr}$ in a low extent $(<10 \%)$. This parameter is notably known to influence metal speciation and subsequently, metal bioaccumulation (Niyogi and Wood, 2004). Besides, such contrasting effects of $\mathrm{pH}$ on bioaccumulations of metals were reported in Daphnia magna (Komjarova and Blust, 2009). Regarding major cations, $\mathrm{Ca}$ concentration in water significantly decreased metal bioaccumulation for most metals, i.e. $\mathrm{Cd}, \mathrm{Co}, \mathrm{Cr}, \mathrm{Cu}, \mathrm{Mn}$ and $\mathrm{Ni}$, whereas $\mathrm{Na}$ concentration essentially increased $\mathrm{Ni}$ and $\mathrm{Zn}$ bioaccumulation in caged mussels. In various freshwater species including zebra mussels, calcium cations are usually reported to compete with metals at the binding sites of biological membranes, decreasing subsequently bioavailability for almost all tested metals (Komjarova and Blust, 2009; Bourgeault et al., 2010a; Peters et al., 2011; Urien et al., 2015). Nevertheless, effect of $\mathrm{Ca}$ on $\mathrm{Cu}$ uptake by aquatic organisms remains poorly documented and anecdotal insofar as $\mathrm{Cu}$ is assumed to cross biological membranes through $\mathrm{Cu}$-specific or $\mathrm{Na}$ channels (Lebrun et al., 2012). Positive Na effect on Zn and $\mathrm{Ni}$ contents in caged mussels can be explained by physiological responses to counteract the effect of low salinity on ionoosmoregulation, as described in amphipods (Marsden and Rainbow, 2004; Verschoor et al., 2012). 

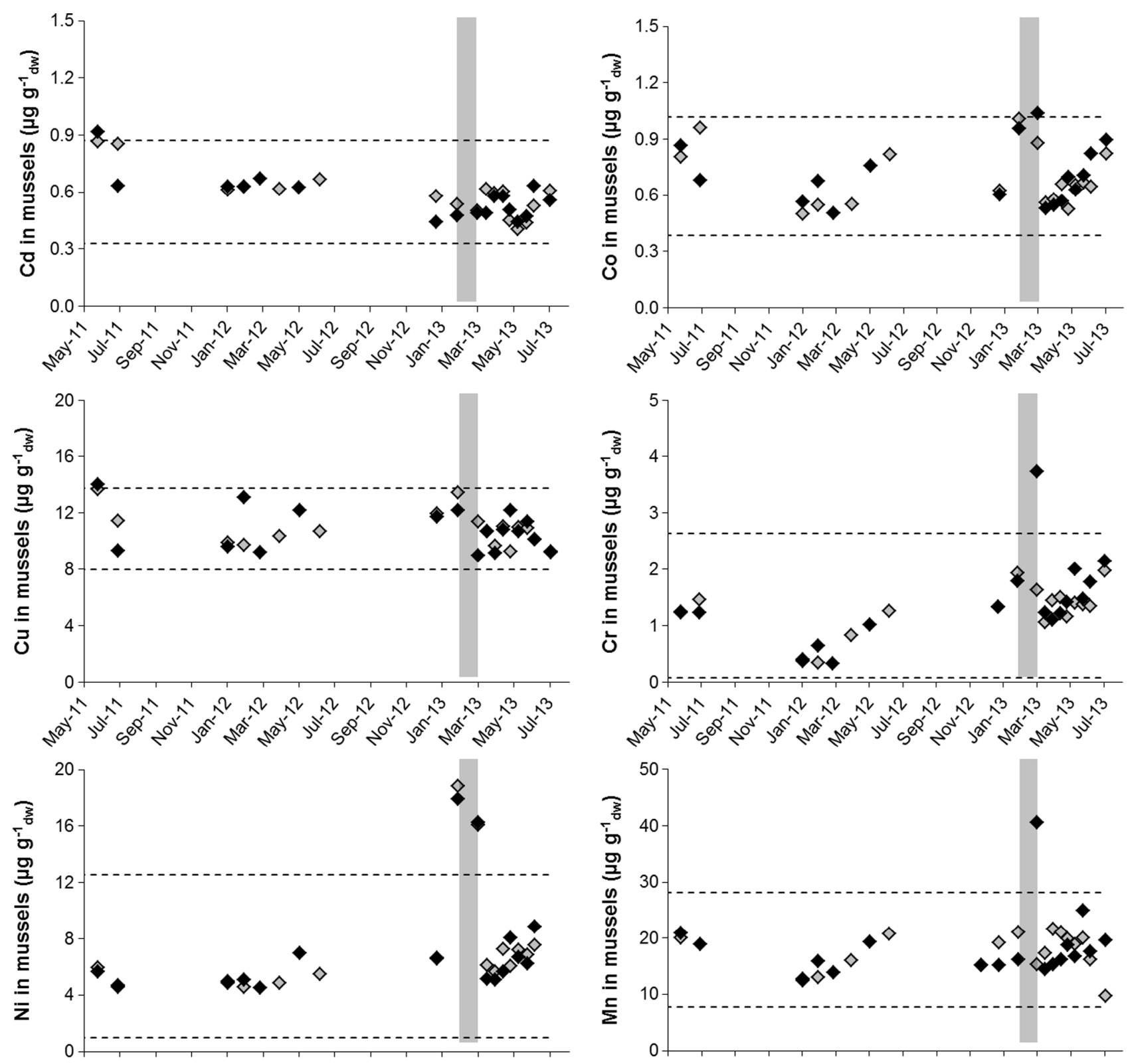

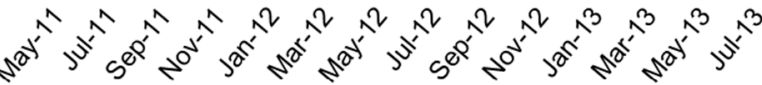
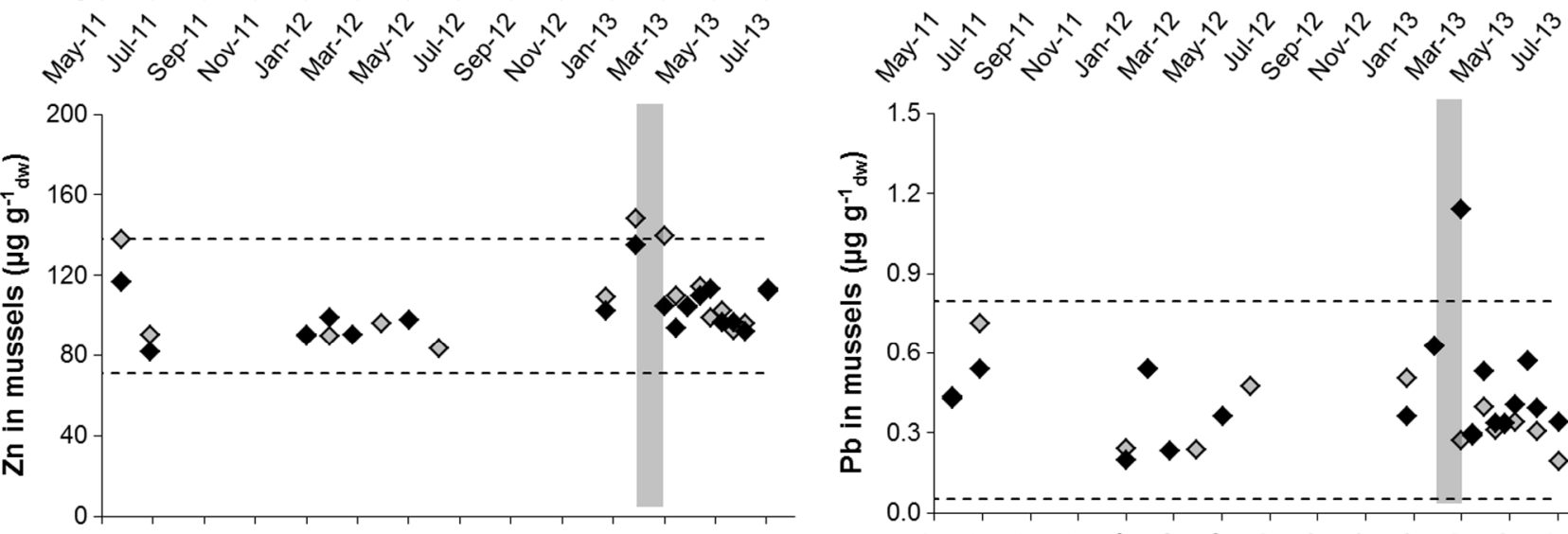

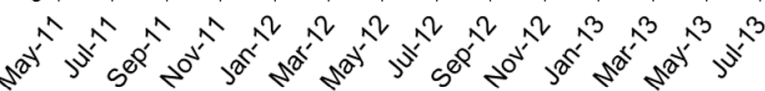

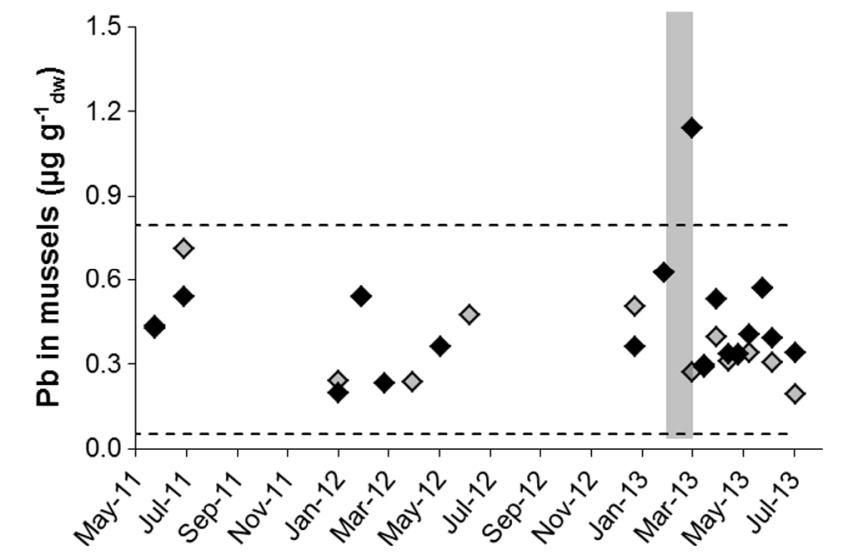

Fig. 3. Metal concentration in zebra mussels transplanted at the upstream ( $\downarrow)$ and downstream $(\diamond)$ sites of the channel of Alsace during the longterm monitoring from March 2011 to July 2013. The dotted lines are 95\% prediction intervals (from bioaccumulation data for both confounded sites). The grey bar corresponds to the 5 -weeks period of dredging. 
J.D. Lebrun et al.: Knowl. Manag. Aquat. Ecosyst. 2017, 418, 54

Table 2. Effects of spatiotemporal, physicochemical factors and metallic fractions of exposure on metal bioaccumulation in caged mussels by ANCOVA: explanatory factors of the variability in \%. Significant effects of factors are in bold $(P<0.05)$.

\begin{tabular}{|c|c|c|c|c|c|c|c|c|c|c|c|}
\hline & \multicolumn{11}{|c|}{ Explanatory factors of variability } \\
\hline & \multicolumn{2}{|c|}{ Spatiotemporal } & \multicolumn{6}{|c|}{ Physicochemistry } & \multicolumn{2}{|c|}{ Exposure level } & \multirow[t]{2}{*}{ Residual variability } \\
\hline & Site & Year & Temp. & TSS & DOC & $\mathrm{pH}$ & $\mathrm{Ca}$ & $\mathrm{Na}$ & Dissol. & Particul. & \\
\hline Cd & 0.5 & 27.2 & 3.0 & 1.7 & 8.9 & 8.9 & 20.7 & 0.6 & 9.0 & 3.6 & 24.8 \\
\hline Co & 0.3 & 4.4 & 2.0 & 1.2 & 2.4 & 0.0 & 37.4 & 1.1 & 2.2 & 32.7 & 18.5 \\
\hline $\mathbf{C r}$ & 3.6 & 27.8 & 4.8 & 0.1 & 0.2 & 7.8 & 11.7 & 0.8 & 8.9 & 21.2 & 22.0 \\
\hline $\mathbf{C u}$ & 1.6 & 15.4 & 1.3 & 1.3 & 2.1 & 0.3 & 26.9 & 0.9 & 12.7 & 18.4 & 31.8 \\
\hline Mn & 2.8 & 1.8 & 11.6 & 0.9 & 27.3 & 5.2 & 18.1 & 6.2 & 8.9 & 4.2 & 21.7 \\
\hline $\mathbf{N i}$ & 0.6 & 15.2 & 1.4 & 9.2 & 0.0 & 0.9 & 12.2 & 8.5 & 1.5 & 21.0 & 30.9 \\
\hline $\mathbf{P b}$ & 0.8 & 4.2 & 0.1 & 7.0 & 0.2 & 0.0 & 2.0 & 1.6 & 0.0 & 46.6 & 37.5 \\
\hline $\mathbf{Z n}$ & 4.3 & 28.4 & 0.1 & 8.2 & 0.6 & 0.2 & 4.3 & 8.2 & 0.5 & 18.6 & 27.2 \\
\hline
\end{tabular}

During the long-term monitoring, statistical analyses confirm that the particulate fraction was the major exposure route for caged mussels in the case of $\mathrm{Co}, \mathrm{Cr}, \mathrm{Cu}, \mathrm{Ni}, \mathrm{Pb}$ and $\mathrm{Zn}$ (Tab. 2). By contrast, the dissolved fraction was the preponderant of exposure route for $\mathrm{Cd}$ and $\mathrm{Mn}$. Such significant uptake of $\mathrm{Cd}$ from the dissolved fraction has been reported in zebra mussels in laboratory conditions (Bourgeault et al., 2010a). The low effect of exposure levels on bioaccumulation of $\mathrm{Mn}$ in caged mussels can be due both to variations in total concentrations in the Rhine water that are too low to induce significant changes in bioaccumulation (Fig. S1) and to the fact that essential metals are known to be well regulated by aquatic organisms so as to maintain constant internal levels for physiological needs (Bervoets et al., 2005; Peters et al., 2011; Lebrun et al., 2014).

The results confirm that the link between exposure and bioaccumulation levels is not straightforward because of metal-specific and complex combinations of biotic and abiotic factors influencing metal uptake by zebra mussels, particularly in low contamination contexts. Furthermore, the non-negligible residual variability observed for all metals (about 25\%) suggests the involvement of other parameters influencing metal bioaccumulation, which are not identified in our study (e.g. quality of organic carbon). Nevertheless, the statistical analyses by ANCOVA confirm that $\mathrm{Ca}$ concentration is a major physicochemical factor that may influence the bioaccumulation of most of tested metals. Moreover, these analyses support the importance of the contamination of mussels from particulate fraction whereas this exposure route is not taken into account in current European and French regulations insofar as they are based on the dissolved fraction.

\subsection{Impact of dredging on metal distribution of the Rhine water}

The natural variability in metal contamination of trapped SPM in the channel of Alsace during the long term-monitoring is presented in Figure 4. The normal ranges obtained in the Rhine water were overall lower than the reference objectives of the International Commission for the Protection of the Rhine or CIPR, i.e. $1,50,50,100$ and $200 \mathrm{mg} \mathrm{kg}^{-1}$ of SPM for $\mathrm{Cd}, \mathrm{Cu}$, $\mathrm{Ni}, \mathrm{Pb}$ and $\mathrm{Zn}$ respectively (Report CIPR n 193, 2008).
During other research works in parallel of this study, pumps had been placed at the upstream and downstream sites to supply continuously water to experimental channels during the 5 weeks of dredging. Thus, metal concentrations of sediments collected at the bottom of both channels at the end of the experiment were compared to the natural variability in metal contamination of trapped SPM in order to detect changes in particulate contamination due to the remobilisation of sediments by pumping/dilution. The results showed that dredging did not significantly modify the contamination levels of SPM, except for $\mathrm{Cu}$ and to a lesser extent for $\mathrm{Zn}$ (Fig. 4). For $\mathrm{Cu}$, the value exceeded the reference of $50 \mathrm{mg} \mathrm{kg}^{-1}$ proposed by CIPR, unlike $\mathrm{Zn}\left(<200 \mathrm{mg} \mathrm{kg}^{-1}\right)$. These results suggest that dredging generated SPM more loaded in $\mathrm{Cu}$ and $\mathrm{Zn}$ that SPM circulating in the Rhine water. This change in $\mathrm{Cu}$ and $\mathrm{Zn}$ concentrations of SPM can be due to the modification of its composition and/or properties favouring the complexation of these particular metals or to the resuspension of highly contaminated sediments impacting the contamination levels of SPM despite the pumping/dilution process. Indeed, $\mathrm{Cu}$ and $\mathrm{Zn}$ are known to be historical contaminants in SPM exceeding the reference objectives of CIPR for the Rhine since the $90 \mathrm{~s}$ (Report CIPR n 193, 2008).

Figure 5 shows that the deployment of DGTs during the 5 weeks of dredging showed that the operation of maintenance of the dam led to a significant increase in Co and Mn under labile chemical forms, as also detected from prediction intervals of natural variability of their lability (Fig. S3). By contrast, the DGT-labile $\mathrm{Cu}$ and $\mathrm{Zn}$ significantly decreased at the downstream site when compared to the upstream site. This argues in favour of a change in $\mathrm{Cu}$ and $\mathrm{Zn}$ speciation reflecting a shift in metal partitioning because of the changes in nature and complexing properties of SPM, as previously assumed. This is consistent with the increase of $\mathrm{Cu}$ and $\mathrm{Zn}$ concentrations in SPM collected at the downstream site receiving the effluent of pumping/dilution (Fig. 4) whereas no significant changes in total metal concentrations were observed (Fig. S1). The results support that the dredging operation led to changes both in the lability of several metals (i.e. $\mathrm{Co}, \mathrm{Cu}, \mathrm{Mn}$ and $\mathrm{Zn}$ ) and the partitioning of $\mathrm{Cu}$ and $\mathrm{Zn}$ between dissolved and particulate fractions. Such changes can then generate modulations in metal bioaccumulation in zebra mussels by favouring or not their uptake from dissolved and/or particulate routes. 


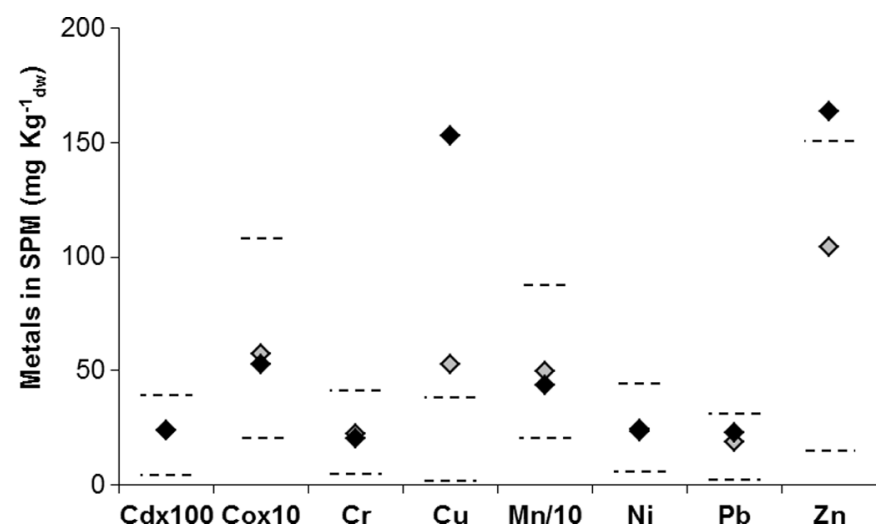

Fig. 4. Metal concentrations insuspended particulate matterscollected in experimental channels at the upstream $(\diamond)$ and downstream $(\diamond)$ sites from the discharge area measured during the 5-week operation of dredging. The dotted lines are 95\% prediction intervals of metal concentrations in SPM trapped in the Rhine water during the longterm monitoring ( $n=16$ data). For $\mathrm{Cd}$, Co and Mn, concentrations were adapted by using a scaling factor.

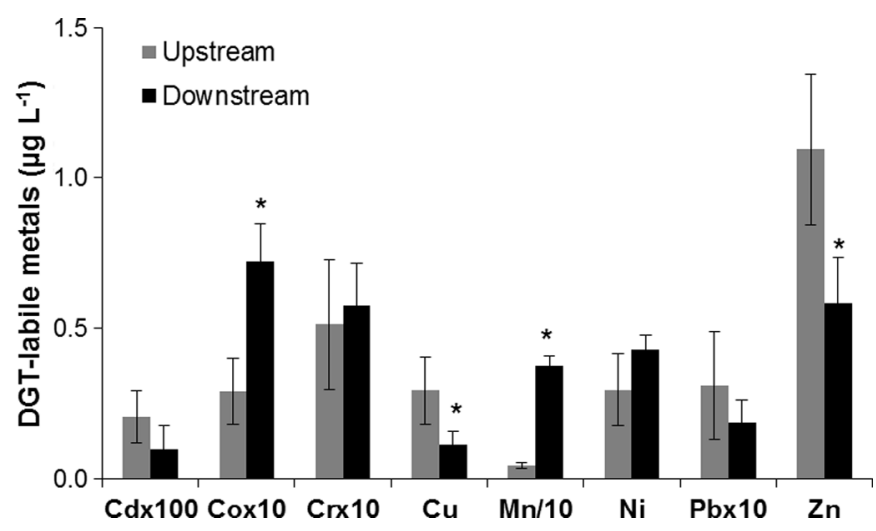

Fig. 5. DGT-labile metal concentrations at the upstream and downstream sites from the discharge of pumping/dilution. Bars are means of three deployed DGT $(n=3 \pm \mathrm{SD})$. For $\mathrm{Cd}$, Co, Cr, Mn and $\mathrm{Pb}$, concentrations were adapted by using a scaling factor. ${ }^{*}$ Significant statistical difference between both sites $(U$-test; $P<0.05)$.

\subsection{Impact of dredging on metal bioaccumulation}

Changes in metal contamination of caged mussels during the dredging operation are presented in Figure 6. By comparison with the upstream site, significant accumulation of $\mathrm{Co}, \mathrm{Cr}, \mathrm{Mn}$ and $\mathrm{Pb}$ was observed in mussels caged at the downstream site, as also detected from the quantification of natural variability (Fig. 3). For $\mathrm{Mn}$ and $\mathrm{Co}$, accumulation by mussels exposed to the discharge is consistent with the increase of labile species ( $c f$. Fig. 5), which are thus mobile and available for aquatic organisms, as showed for gammarids with $\mathrm{Cd}$ and $\mathrm{Cu}$ (Pellet et al., 2009; Ferreira et al., 2013). For $\mathrm{Cr}$ and $\mathrm{Pb}$, the increase in bioaccumulation could be explained by the enrichment of the effluent of pumping/dilution in organic matter and changes in SPM

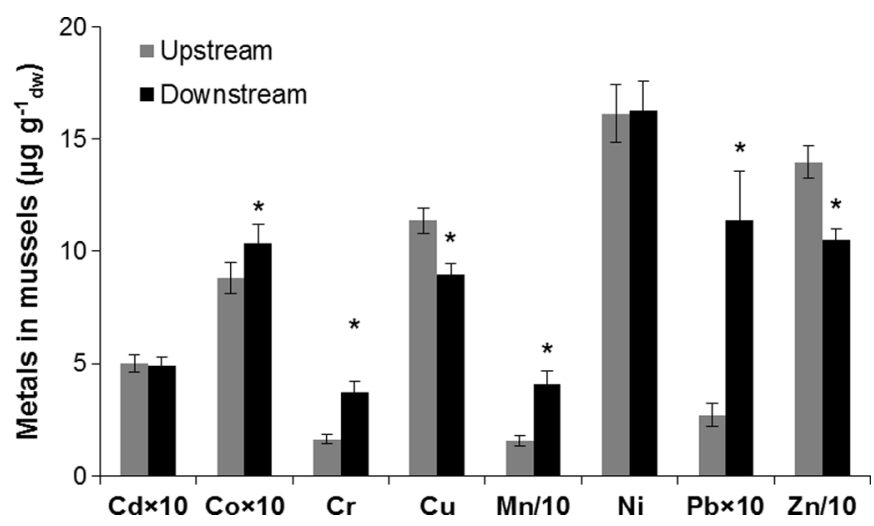

Fig. 6. Mean metal concentrations in mussels caged at the upstream and downstream sites from the discharge of pumping/dilution. For Cd, $\mathrm{Co}, \mathrm{Pb}$ and $\mathrm{Zn}$, concentrations were adapted by using a scaling factor. ${ }^{*}$ Significant statistical difference between both sites ( $U$-test; $P<0.05)$.

properties, hence enhancing their particulate bioavailability and subsequently their assimilation by mussels (Roditi et al., 2000; Bourgeault et al., 2010a; Bourgeault et al., 2011). By contrast, $\mathrm{Cu}$ and $\mathrm{Zn}$ concentrations in exposed mussels were lower than unexposed mussels. This is likely due to the decrease of their lability and high complexation with remobilised sediments limiting their mobility and exchangeability with biological membranes, as previously discussed (Figs. 4 and 5).

Although dredging led to significant bioaccumulation of $\mathrm{Co}, \mathrm{Cr}, \mathrm{Mn}$ and $\mathrm{Pb}$ in mussels exposed to the discharge, the mussels recovered to be within their initial internal metal levels 2 weeks after the end of dredging (Fig. 3). These results confirm the ability of zebra mussels to actively regulate metals and to excrete them from their tissues (Roditi and Fisher, 1999; Bourgeault et al., 2011). Besides, these results highlight that the dredging operation had a transient effect on caged mussels when considering both metal bioaccumulation and mortality. Nevertheless, we cannot exclude that the short-term exposure of mussels to the discharge did not induce any sub-lethal effects (Bourgeault et al., 2010b). Besides, the dredging might also lead to the remobilisation of other persistent contaminants including organic compounds, with potential adverse effects for biota. In particular, the Rhine River has been historically contaminated by hexachlorobenzene known to accumulate in sediments due to its hydrophobic character (Beurskens et al., 1992). Further studies focusing on organic compounds will allow to obtain an extended environmental assessment of the impact of dredging on this aquatic ecosystem.

\section{Conclusions}

The long-term monitoring performed in the Rhine water allowed the establishment of reference baselines of metal concentrations in labile, dissolved, particulate and total fractions in a European River. Results supports that the metal uptake from the particulate phase constitutes a major route of exposure for mussels, except for $\mathrm{Cd}$ and $\mathrm{Mn}$. Nevertheless, the current EQSs based on the dissolved fraction do not take into account this exposure route, hence limiting their protective interest for 
aquatic organisms, in particular for filter feeders. Furthermore, this monitoring experiment makes evidence that the dredging operation affected both metal partitioning between water fractions and metal contamination levels in transplanted mussels. Indeed, quantifying the natural variability of metal bioaccumulation during full hydrological cycles allowed the detection of significant increases in $\mathrm{Co}, \mathrm{Cr}, \mathrm{Mn}$ and $\mathrm{Pb}$ bioaccumulation in mussels exposed to the effluent of pumping/ dilution. In the case of $\mathrm{Co}$ and $\mathrm{Mn}$, the increased bioaccumulation can be explained by the increase of these metals under labile species that are subsequently more bioavailable for the organisms. The increased mussel contamination in $\mathrm{Cr}$ and $\mathrm{Pb}$ is likely due to an enhanced particulate bioavailability from dredged sediments. By contrast, despite a remobilisation of SPM-bound $\mathrm{Cu}$ and $\mathrm{Zn}$, no significant increase in bioaccumulation was observed for both essential metals. This highlights the interest of coupling chemical and biological tools for a better assessment of environmental risks because metallic exchanges between organisms and their media are complex and metalspecific. Whatever the exposure route, the fact that caged mussels recovered their basal metal contents 2 weeks after the end of the dredging operation suggests a transient impact of the discharge on exposed mussels in terms of bioaccumulation for the metals considered in this study. Nevertheless, sub-lethal effects in mussels exposed to the discharge are likely and remain to be assessed. Besides, further studies focusing on organic compounds will allow to obtain an extended environmental assessment of the impact of dredging on this aquatic ecosystem.

\section{Supplementary Material}

Supplementary figures and tables.

The Supplementary Material is available at https:/www.kmaejournal.org/10.1051/kmae $/ 2017049 / \mathrm{olm}$.

Acknowledgments. The present study was supported by the French firm EDF. The authors are sincerely grateful to Aurélie Germain for her active contribution during the sampling campaigns.

\section{References}

Baines SB, Fisher NS. 2008. Modeling the effect of temperature on bioaccumulation of metals by a marine bioindicator organism, Mytilus edulis. Environ Sci Technol 42: 3277-3282.

Barrett TJ, Hille KA, Sharpe RL, Harris KM, Machtans HM, Chapman PM. 2015. Quantifying natural variability as a method to detect environmental change: definitions of the normal range for a single observation and the mean of m observations. Environ Toxicol Chem 34: 1185-1195.

Bervoets L, Voets J, Covaci A, Chu SG, Qadah D, Smolders R, Schepens P, Blust R. 2005. Use of transplanted zebra mussels (Dreissena polymorpha) to assess the bioavailability of microcontaminants in flemish surface waters. Environ Sci Technol 39: 1492-1505.

Besse JP, Geffard O, Coquery M. 2012. Relevance and applicability of active biomonitoring in continental waters under the water framework directive. Trac-Trends Anal Chem 36: 113-127.

Beurskens JE, Dekker CG, Jonkhoff J, Pompstra L. 1992. Microbial dechlorination of hexachlorobenzene in a sedimentation area of the Rhine River. Biogeochemistry 19: 61-81.
Bisson M, Gay G, Houeix N, Lacroix G, Lefevre JP, Magaud V, Migne A, Morin A, Tossot S. 2006. French Expertise Report on Cobalt. http://www.ineris.fr.

Bisson M, Bureau J, Houeix N, Jolibois B, Gay G, Lefevre JP, Tack K. 2011. French Expertise Report on Manganese. http://www.ineris.fr. Bourgeault A, Gourlay-France C, Tusseau-Vuillemin MH. 2010a. Modeling the Effect of Water Chemistry on the Bioaccumulation of Waterborne Cadmium in Zebra Mussels. Environ Toxicol Chem 29: 2182-2189.

Bourgeault A, Gourlay-France C, Vincent-Hubert F, Palais F, Geffard A, Biagianti-Risbourg S, et al. 2010b. Lessons from a Transplantation of Zebra Mussels into a Small Urban River: an Integrated Ecotoxicological Assessment. Environ Toxicol 25: 468-478.

Bourgeault A, Gourlay-France C, Priadi C, Ayrault S, TusseauVuillemin MH. 2011. Bioavailability of particulate metal to zebra mussels: biodynamic modelling shows that assimilation efficiencies are site-specific. Environ Pollut 159: 3381-3389.

Directive 2013/39/UE. 2013. Directive of the European Parliament and the Council of the European Union for environmental quality standards in the field of water policy (WFD). Official Journal of European Communities, http://eur-lex.europa.eu/.

Faburé J, Dufour M, Autret A, Uher E, Fechner LC. 2015. Impact of an urban multi-metal contamination gradient: Metal bioaccumulation and tolerance of river biofilms collected in different seasons. Aquat Toxicol 159: 276-289.

Fechner LC, Gourlay-Francé C, Bourgeault A, Tusseau-Vuillemin MH. 2012. Diffuse urban pollution increases metal tolerance of natural heterotrophic biofilms. Environ Pollut 162: 311-318.

Ferreira D, Ciffroy P, Tusseau-Vuillemin M-H., Garnier C, Garnier J-M. 2009. Modelling exchange kinetics of copper at the water-aquatic moss (Fontinalis antipyretica) interface: influence of water cationic composition (Ca, Mg, Na and pH). Chemosphere 74: 1117-1124.

Ferreira D, Ciffroy P, Tusseau-Vuillemin MH, Bourgeault A, Gamier JM. 2013. DGT as surrogate of biomonitors for predicting the bioavailability of copper in freshwaters: an ex situ validation study. Chemosphere 91: 241-247.

Galvao P, Longo R, Torres JPM, Malm O. 2015. Estimating the potential production of the brown mussel Perna perna (Linnaeus, 1758) reared in three tropical bays by different methods of condition indices. J Mar Biol 2015: 11.

Komjarova I, Blust R. 2009. Effect of $\mathrm{Na}, \mathrm{Ca}$ and $\mathrm{pH}$ on simultaneous uptake of $\mathrm{Cd}, \mathrm{Cu}, \mathrm{Ni}, \mathrm{Pb}$, and $\mathrm{Zn}$ in the water flea Daphnia magna measured using stable isotopes. Aquat Toxicol 94: 81-86.

Kraak MHS, Scholten MCT, Peeters WHM, de Kock WC. 1991. Biomonitoring of heavy metals in the Western European Rivers Rhine and Meuse using the freshwater mussel Dreissena polymorpha. Environ Pollut 74: 101-114.

Kwan KHM, Chan HM, De Lafontaine Y. 2003. Metal Contamination in zebra mussels (Dreissena polymorpha) Along the st. Lawrence River. Environ Monit Assess 88: 193-219.

Lebrun JD, Perret M, Geffard A, Gourlay-Francé C. 2012. Modelling copper bioaccumulation in Gammarus pulex and alterations of digestive metabolism. Ecotoxicology 21: 2022-2030.

Lebrun JD, Uher E, Tusseau-Vuillemin M-H, Gourlay-Francé C. 2014. Essential metal contents in indigenous gammarids related to exposure levels at the river basin scale: metal-dependent models of bioaccumulation and geochemical correlations. Sci Total Environ 466-467: 100-108.

Lebrun JD, Geffard O, Urien N, François A, Uher E, Fechner LC. 2015. Seasonal variability and inter-species comparison of metal bioaccumulation in caged gammarids under urban diffuse contamination gradient: implications for biomonitoring investigations. Sci Total Environ 511: 501-508. 
Marsden ID, Rainbow PS. 2004. Does the accumulation of trace metals in crustaceans affect their ecology-the amphipod example? $J$ Exp Mar Biol Ecol 300: 373-408.

Niyogi S, Wood CM. 2004. Biotic ligand model, a flexible tool for developing site-specific water quality guidelines for metals. Environ Sci Technol 38: 6177-6192.

Pellet B, Geffard O, Lacour C, Kermoal T, Gourlay-Francé C, Tusseau-Vuillemin MH. 2009. A model predicting waterborne cadmium bioaccumulation in Gammarus pulex: The effects of dissolved organic ligands, calcium, and temperature. Environ Toxicol Chem 28: 2434-2442.

Peters A, Lofts S, Merrington G, Brown B, Stubblefield W, Harlow K. 2011. Development of biotic ligand models for chronic manganese toxicity to fish, invertebrates, and algae. Environ Toxicol Chem 30: 2407-2415.

Priadi C, Bourgeault A, Ayrault S, Gourlay-France C, TusseauVuillemin MH, Bonte P, Mouchel JM. 2011. Spatio-temporal variability of solid, total dissolved and labile metal: passive vs. discrete sampling evaluation in river metal monitoring. $J$ Environ Monit 13: 1470-1479.

Rainbow PS. 2007. Trace metal bioaccumulation: models, metabolic availability and toxicity. Environ Int 33: 576-582.

Report CIPR n 193. 2008. Comparaison entre l'état réel et l'état souhaité du Rhin de 1990 et 2008. www.iksr.org.
Roditi HA, Fisher NS. 1999. Rates and routes of trace element uptake in zebra mussels. Limnol Oceanogr 44: 1730-1749.

Roditi HA, Fisher NS, Sanudo-Wilhelmy SA. 2000. Uptake of dissolved organic carbon and trace elements by zebra mussels. Nature 407: 78-80.

Roussel H, Chauvet E, Bonzom JM. 2008. Alteration of leaf decomposition in copper-contaminated freshwater mesocosms. Environ Toxicol Chem 27: 637-644.

Tusseau-Vuillemin MH, Gourlay C, Lorgeoux C, Mouchel JM, Buzier R, Gilbin R, Seidel JL, Elbaz-Poulichet F. 2007. Dissolved and bioavailable contaminants in the Seine river basin. Sci Total Environ 375: 244-256.

Uher E, Mirande-Bret C, Gourlay-Francé C. 2011. Lessons from a large scale deployment of DGT in the Seine basin. RSC Environ Chem Group Bull 1: 1-8.

Urien N, Uher E, Billoir E, Geffard O, Fechner LC, Lebrun JD. 2015. A biodynamic model predicting waterborne lead bioaccumulation in Gammarus pulex: influence of water chemistry and in situ validation. Environ Pollut 203: 22-30.

Verschoor AJ, Hendriks AJ, Vink JPM, de Snoo GR, Vijver MG. 2012. Multimetal accumulation in crustaceans in surface water related to body size and water chemistry. Environ Toxicol Chem 31: 2269-2280.

Cite this article as: Lebrun JD, Dufour M, Uher E, Faburé J, Mons R, Charlatchka R, Gourlay-Francé C, Fechner LC, Ferrari BJD. 2017. To what extend the dam dredging can influence the background level of metals in the Rhine River: using chemical and biological long-term monitoring to answer. Knowl. Manag. Aquat. Ecosyst., 418, 54. 